University of Wollongong

Research Online

Faculty of Business - Papers (Archive)

Faculty of Business and Law

2013

Trade liberalisation, labour productivity growth and skilled labour complement: evidence from the Thai manufacturing sector

Piyapong Sangkaew

University of Wollongong, ps650@uowmail.edu.au

Kankesu Jayanthakumaran

University of Wollongong, kankesu@uow.edu.au

Follow this and additional works at: https://ro.uow.edu.au/buspapers

Part of the Business Commons

Research Online is the open access institutional repository for the University of Wollongong. For further information contact the UOW Library: research-pubs@uow.edu.au 


\title{
Trade liberalisation, labour productivity growth and skilled labour complement: evidence from the Thai manufacturing sector
}

\author{
Abstract \\ Trade liberalisation in Thailand raised two wider questions regarding the labour market-one with regards \\ to the link with labour productivity and the other the link with skilled workers. This outcome provides a link \\ between (1) trade liberalisation and labour productivity growth, and, (2) skilled employment and labour \\ productivity growth. Trade liberalisation is also correlated with skilled employment. This type of evidence \\ matches conventional explanations for the beneficial allocation of trade liberalisation and demanding \\ skills training for potential future industrial growth.

\section{Keywords} \\ liberalisation, labour, productivity, growth, skilled, complement, evidence, thai, manufacturing, sector, trade \\ Disciplines \\ Business

\section{Publication Details} \\ Sangkaew, P. \& Jayanthakumaran, K. (2013). Trade liberalisation, labour productivity growth and skilled \\ labour complement: evidence from the Thai manufacturing sector. In V. Huynh, V. Kreinovich, S. \\ Sriboonchitta \& K. Suriya (Eds.), Uncertainty Analysis in Econometrics with Applications - Advances in \\ Intelligent Systems and Computing, Vol 200 (pp. 203-213). Heidelberg: Springer.
}




\title{
Trade Liberalisation, Labour Productivity Growth and Skilled Labour Complement: Evidence from the Thai Manufacturing Sector
}

\author{
Piyapong Sangkaew and Kankesu Jayanthakumaran
}

\begin{abstract}
Trade liberalisation in Thailand raised two wider questions regarding the labour market-one with regards to the link with labour productivity and the other the link with skilled workers. This outcome provides a link between (1) trade liberalisation and labour productivity growth, and, (2) skilled employment and labour productivity growth. Trade liberalisation is also correlated with skilled employment. This type of evidence matches conventional explanations for the beneficial allocation of trade liberalisation and demanding skills training for potential future industrial growth.
\end{abstract}

\section{Introduction}

Trade liberalisation policy has been implemented by countries to stimulate economic and employment growth. However, there have been longstanding concerns about the possible job displacement effects of trade liberalisation and other measures introduced to lift productivity.

Beaudry and Collard [2], for example, explain that reducing controls on trade causes a drastic technological change, and makes human capital the factor for determining the growth in labour productivity while also raising the demand for more skilled workers. Davis and Harrigan [5] explained that trade liberalisation and productivity have been found to be biased toward skilled workers. Thailand accelerated trade liberalisation in the early 1990s such that simple average tariff rates on industrial products decreased from 43.5 per cent in 1991 to 14.6 per cent in 1999 [15],

Piyapong Sangkaew Ph.D Candidate

School of Economics, University of Wollongong, NSW2522, Australia, e-mail: ps650@uowmail.edu.au

Kankesu Jayanthakumaran

School of Economics, University of Wollongong NSW 2522, Australia, e-mail: kankesu@uow.edu.au 


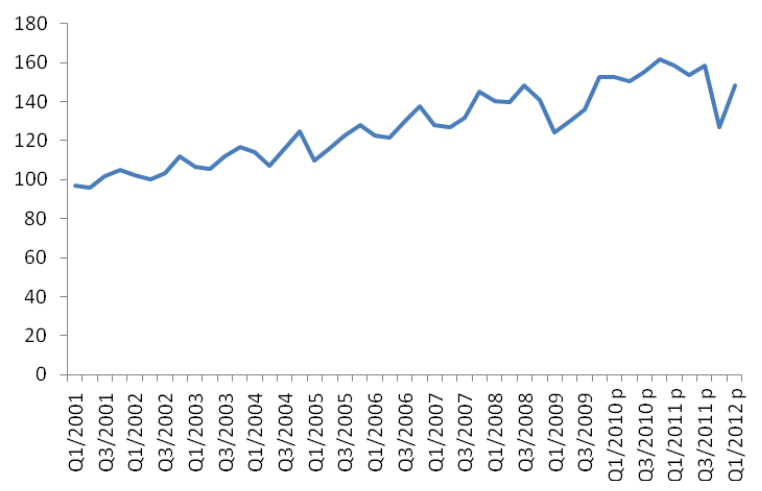

Fig. 1 Labour Productivity Per Employed Person between 2001 and 2010

and the next stage of reforms started in 1999 after a brief setback during the Asian crisis in 1997/98. This paper intends to study the link between trade liberalisation, labour productivity, and skilled employment. The next section shows trade liberalisation and labour productivity in Thailand, the third section shows the method and data used in this study, the fourth section shows the empirical results, and the fifth section provides the conclusion.

\section{Trade Liberalization and Labour Productivity}

The first round of tariff restructuring began in the early 1990s and was completed in 1997. Subsequently, the structure of Thailand's tariff was reduced from 39 tariff rate categories to only six in this period. It has restructured customs tariff on nine product categories covering a total of 2,990 items, or 39.52 per cent of all customs tariff items. The second round of tariff restructuring was in 1999 and was implemented immediately after the Asian crisis (Appendix 1). Tariffs on capital goods, raw materials, and other products, including more than 630 items, were either reduced or exempted on a permanent basis, for example (i) the 10 per cent import duty surcharge was removed, (ii) tariffs on machinery and mechanical appliances and parts were reduced, and (iii) tariffs on electrical machinery and equipment parts were reduced from 5 and 20 per cent to 3 per cent for 326 items.

A visual inspection of Figure 1 shows that the labour productivity of the manufacturing sector has, in general, been increasing since 2001, although the fall in 2009 and 2011 may be associated with a fall in output due to the global crisis. Labour productivity in 1999 was almost two times higher than in 1991 [12]. Phan [15] found that trade liberalisation had increased both the labour and total factor productivity growth.

However, gains in labour productivity (higher output per worker) resulting from labour saving technologies may lead to job destruction ([3], [7], [11]) because 


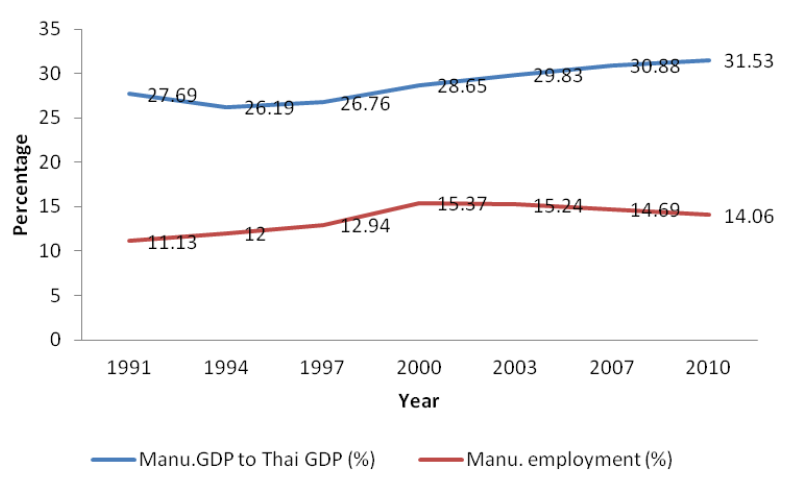

Fig. 2 Labour Productivity Per Employed Person between 2001 and 2010

competitive pressures can drive investment, innovation, skills upgrading, and other factors in the overall development process. Even higher productivity spurs economic growth and expands employment overall, although labour saving technological changes and the relative growth and decline of specific sectors results in job losses in some places and some industries, for actual workers, enterprises, and communities.

Upon careful examination of Figure 2, even though the percentage of employment between 1997 and 2000 had increased, employment in the manufacturing sector gradually decreased from 15.37 per cent to 14.06 per cent respectively, between 2000 and 2007. This trend had changed from the percentage of manufacturing GDP to overall GDP, which had increased over the same period from 1991 to 2010. The percentage of employment in the Thai manufacturing sector had not kept up with an increase in the share of manufacturing GDP. Thus, employment-productivity tradeoff problems should be taken into account mainly because the policy of stimulating trade and productivity might decrease employment in this sector.

Table 1 Correlation between Manufacturing Tariffs and Labour Productivity between 1991 and 2007

\begin{tabular}{llll}
\hline & & \\
& \multicolumn{2}{c}{ Skilled-Total Employment Ratio LP } & Tariff \\
\hline Skilled-Total Employment Ratio & 1.000 & & \\
Real LP* & 0.178 & 1.000 & \\
Tariff** & -0.057 & -0.131 & 1.000 \\
\hline
\end{tabular}

Source: Calculated by the author from the Industrial Surveys [20]. *: The value used in a natural $\log$ form. ${ }^{*}$ Tariff data is provided in an appendix 1.

Table 1 shows the correlation of variables; skilled-total employment, labour productivity (LP) and tariffs in the Thai manufacturing sector. There are negative correlations between (i) tariff and labour productivity, and (ii) tariff and productivity, 
which are -0.131 and -0.057 respectively. This value implies that a decreasing tariff correlates to an increase in the LP and skilled-total employment ratio in the manufacturing sector. This should basically support the idea that trade liberalisation increases manufacturing labour productivity and changes the structure of employment by raising the demand for skilled labour in the manufacturing sector.

\section{Method and Data}

Labour productivity $(l p)$ can be defined as value-added per worker. The dependent variable is the growth of labour productivity $(i p)$ during the period 1991, 1994, 1997, 2000, 2003 and 2007. Independent variables have been chosen to reflect trade policy, employment, and structural and technological changes. The labour productivity growth model can be constructed as follow: ${ }^{1}$

$$
\begin{aligned}
\dot{l p}= & \alpha_{0}+\alpha_{1} \dot{k}_{i t}+\alpha_{2}\left(\operatorname{skill}_{i t}\right)+\alpha_{3}\left(e \dot{m} p_{i t}\right)+\alpha_{4}\left(x_{i t}\right) \\
& +\alpha_{5}\left(i_{-} i m_{i t}\right)+\alpha_{6}\left(F D I_{i t}\right)+\alpha_{7}\left(D_{i t}\right)+\varepsilon_{i t}
\end{aligned}
$$

Three trade policy variables-tariffs, intermediate tariffs, and exports-have been used to capture the effect of trade liberalisation on $i p$. The reductions in tariffs reflects the response by local firms, and local firms tend to match a new set of relative prices that are closer to international prices and which stimulate resources in line with comparative advantages. The reduction in tariffs, therefore, are expected to have a negative effect on $\dot{l p}$. Firms target greater technical change in an open trading environment in order to achieve sustainable long term rates of growth. As a result, intermediate-input import per worker is expected to have a positive effect on labour productivity growth.

Exports per worker are normally used as a proxy variable of trade liberalisation in empirical studies to explain productivity. Exports are found to stimulate firms or industrial labour productivity. Jonsson and Subrmanian [9] and Sjoholm [19] explain that export firms tend towards new technology and produce higher quality products. Moreover, exporting firms have a higher price margin than non-exporting firms, which raises an export firms' labour productivity. Therefore, export growth is expected to have a positive effect on industrial labour productivities in this study [13]. If there are expected signs and significant associations between one or more of the trade variables and $i p$ then there will be support for a positive impact of liberalisation on the performance of labour.

Two employment variables, share of skilled employment and overall employment, have been used to reflect the effect of the labour market on $i p$. Skilled employment growth is expected to have a positive effect on $i p$. Generally, skilled workers refers to workers who spend more years in school, so they tend to have high

${ }^{1}$ The expected signs of $\dot{k}_{i t}$, skill $l_{i t}, e \dot{m} p_{i t}, x_{i t}, i_{i} i m i t, F D I_{i t}$ are,,,,,,$++-++++/-$, respectively 
human capital accumulation, and as a result they are more productive than unskilled labour. An increase in the number of skilled workers will raise firms' productivity and efficiency [21]. The share of manufacturer employment to the total manufacturing employment is expected to be negatively associated with labour productivity growth due to the effect of "the law of diminishing marginal return". An increase in the number of workers will increase total output diminishingly [22], and as such, increases in a number of workers will cause a decrease in labour productivity.

Two variables, output growth and FDI have been chosen to reflect the structural changes. Output growth is expected to stimulate growth in labour productivity because industry will benefit from an economy of scale [23]. The share FDI per worker reflects an increase of FDI over time. FDI can stimulate growth in labour productivity in many ways, such as (i) providing better knowledge, (ii) giving firms more opportunity to export. One would expect a positive association between output growth and $i p$, and FDI per worker and $i p$.

The capital growth variable represents technological change and is expected to stimulate growth in labour productivity. Capital growth per worker is expected to have a positive effect on the growth of industrial labour productivity.

The data used in this study is from (i) Manufacturing Industrial Survey conducted by the National Statistical Office (NSO), Thailand, and (ii) World Integrated Trade Solution (WITS) which is an organisation under the World Bank. The scope of the manufacturing surveys are firms primarily engaged in manufacturing industries which are classified according to the International Standard Industrial Classification ( ISIC), have 10 or more persons engaged in the business, and cover the whole country. The criticism of Thai manufacturing data by Ramstetter [17], and Ramstetter and Sjoholm [18], have been taken into account such that the following observations have been used; for the years 1991, 1994, 1997, 2000, 2003 and 2007, the observations are $970,969,2,558,2,2853,765,18,620$ respectively ${ }^{2}$.

In this study the Thai manufacturing labour productivities (LP) were calculated from Thai industrial surveys in the selected years 1991, 1994, 1997, 2000, 2003, and 2007. After the labour productivity growth $(i p)$ for each industry and for all the years have been obtained, they become a manufacturing panel data. Overall there were 138 observations of Thai manufacturing labour productivities (23 industries in 6 years). Because the calculated growth in the rate of labour productivity caused this study to lose a year of data (23 observations), the actual observations are 115 .

There are inconsistencies in the availability of data on intermediate-input import, export, and FDI in Thai industrial surveys. To overcome this problem, this study will incorporate the effect of intermediate-input import on $i p$ between 1994-2007, while the effect of export and FDI on $l p$ will cover between 1997 to 2007.

\footnotetext{
2 overall there are 29,167 firms left that are useful for this study (22.86 per cent); (i) 10, 268 firms which did not report the number of workers, (ii) one firm which did not report working hours and days, (iii) 23, 129 firms which did not report wage bills, (iv) 18,831 firms which did not report their income, (vi) two firms which did not have ISIC code, (vii) 1,432 firms which did not report their fixed assets, (viii) 13, 266 firms which did not report their fixed assets (machines), (ix) 5488 firms which have a negative value added, (x) 26, 784 firms which have no skilled workers, and (xi) 223 firms which did not report the number of unskilled workers.
} 


\section{Empirical Results}

To detect multi-collinearity problems, the correlation metrics between independent variables have been checked (Appendix 1). The correlation is low in all cases except for (i) intermediate input import $\left(i_{-} i m\right)$, and export $(x)$ and (ii) capital per worker growth $(\dot{k})$ and per cent change in tariff (tariff), which are 0.6542 and 0.3179 , respectively. As the high correlation among the variables could lead to multi-collinearity problems, this study applies the variance-inflating factor (VIF) to examine whether this would be a critical problem [6] . The calculated VIF is 6.20 which is less than ten per cent, which implies that even though there are multicollinearity problems, they are acceptable [6].

Table 2 Regression Results for the Thai Manufacturing Sector

\begin{tabular}{|c|c|c|c|c|c|c|}
\hline Variables & OLS & $\mathrm{FE}$ & $\mathrm{RE}$ & RE2INPUT & E3EXPORT & RE4FDI \\
\hline & (1) & (2) & (3) & (4) & (5) & (6) \\
\hline$\dot{k}$ & 0.0351 & -0.07783 & 0.0351 & -0.3622 & 0.1323 & $0.2844 * *$ \\
\hline & -0.0779 & -0.0958 & -0.0779 & -0.0778 & -0.0946 & -0.1262 \\
\hline$\dot{y}$ & $0.5195 * * *$ & $0.5062 * * *$ & $0.5195 * * *$ & $0.5142 * * *$ & $0.4898 * * *$ & $0.3436 * * *$ \\
\hline & -0.0418 & -0.0462 & -0.0418 & -0.042 & -0.0483 & -0.0802 \\
\hline tariff & $-0.2348 *$ & $-0.3584 * *$ & $-0.2349 *$ & $-0.2608 * *$ & -0.0528 & 0.0909 \\
\hline & -0.1318 & -0.1512 & -0.1318 & -0.1338 & -0.1725 & -0.1891 \\
\hline skill & 0.1717 & $0.2421 * *$ & $0.1717 *$ & $0.1850 * *$ & $0.2222 *$ & 0.1924 \\
\hline & -0.1037 & -0.1184 & -0.1037 & -0.1043 & -0.1174 & -0.1495 \\
\hline emp & $-0.1353 * * *$ & $-0.1129 * * *$ & $-0.1354 * * *$ & $-0.1333 * * *$ & $-0.0935 * *$ & $-0.0918^{*}$ \\
\hline & -0.0322 & -0.0356 & -0.0322 & -0.0322 & -0.0392 & -0.0498 \\
\hline i_im & & & & -0.0463 & -0.1066 & 0.0931 \\
\hline & & & & -0.0426 & -0.0734 & -0.0879 \\
\hline$x$ & & & & & -0.0012 & -0.0374 \\
\hline & & & & & -0.0812 & -0.1608 \\
\hline FDI & & & & & & $0.0489 * *$ \\
\hline & & & & & & -0.0179 \\
\hline constant & -0.0827 & -0.1009 & -0.0827 & -0.5158 & 1.4517 & -1.3337 \\
\hline & -0.0671 & -0.0709 & -0.0671 & -0.5554 & -0.8953 & -1.0564 \\
\hline Ind.effect. & $\mathrm{NO}$ & YES & YES & YES & YES & YES \\
\hline $\mathrm{N}$ & 85 & 85 & 85 & 85 & 66 & 51 \\
\hline F-test & 38.4971 & 30.4081 & & & & \\
\hline R-squared & 0.709 & 0.7238 & 0.7149 & 0.7123 & 0.7879 & 0.8387 \\
\hline AIC & 147.816 & 126.983 & & . & . & \\
\hline
\end{tabular}

Source: Calculated by the author. Note: Dependent variable: Growth of labour productivity. $*, * *, * * *$; Estimate coefficient is significant at the 10,5 and 1 percent level, respectively.

Table 2 provides empirical results from this study. There are six models which begin with the simple ordinary least squared (OLS) shown in the first column. This is to compare the results and to examine the consistency of the coefficient of variables. Then the fixed effected (FE) and random effected (RE) are shown in columns 2 and 3 , respectively [6]. After that, new variables will continually be added into the model 
to examine whether they are significant in emplaning labour productivity growth $(i p)$ in the Thai manufacturing sector. The best model will be selected based on econometric reasons.

The model 1 in the first column is the OLS pooling the data over the period 1991 to 2007 without industrial effects. The result shows that $\dot{y}$, tariff , and emp significantly affect $i p$ at one, ten and one per cent significance level, respectively. $\dot{y}$ has a positive effect on $i p$ while emp and tariff have a negative effect on $i p$. According to this study, $\dot{y}$ is found to play an important role in contributing to $\dot{l p}$ since a one per cent increases in $\dot{y}$ will increase $\dot{l} p$ around 0.5195 per cent.

A proxy variable of trade liberalisation tariff has a correct and negative sign and is significant at the 10 per cent level. A one per cent decrease in the tariff will increase $i p$ in the Thai manufacturing sector around 0.2348 per cent. Therefore, it can be said that trade liberalisation increases the Thai manufacturing labour productivity.

Employment $(e \dot{m} p)$ is found to have a negative effect on $i p$ and a one per cent increase in $e \dot{m} p$ will decrease $i p$ by 0.1353 per cent. The negative effect of this variable on $i p$ would be a diminishing return or an employment-productivity trade-off, where more employment would reduce the productivity of labour in manufacturing. If other variable constants are held, expanding employment will decrease the labour productivity growth in the Thai manufacturing sector.

Because manufacturers are in various businesses and use different technologies, this may cause them to have different labour productivity growth. This study applied the fixed (FE) and random effect (RE) techniques to control the industry effect, but if the constant value in the model is not systematically changed, the fixed effect is more suitable. However, if it is the random effect becomes more reliable [6]. To examine whether FE or RE is better, the Hausman test is applied and used to answer this question [6]. The result from the calculated Hausman test shows prob $>0.171$ so a null hypothesis is accepted [8], and therefore the RE model provides a better explanation than the fixed effect model. For this reason the following models will be based on the random effect model to explain how trade liberalisation effects the labour productivity growth in the Thai manufacturing sector.

The RE model 3 shows that $\dot{y}$, emp and tariff are still significant and have almost the same coefficients as the OLS model. In model 4, i_im is added into the model, which means that all the explanatory variables remain almost the same. The new variable has an expected sign but it is not significant.

In model 5 the export variable is added into the model and yields a better result. Compared with model 2, r-squared in e model 5 is higher, increasing from 0.72 in model 2 to 0.78 in model 4 . However, the new variable added into this model is not significant so in this model, only $\dot{y}$, skill and emp remain significant but have lower coefficients.

In model 6, FDI is added into the model. The result shows that FDI is positively significant in giving an explanation for in the Thai manufacturing sector. In this model the r-squared increases significantly from around 78 per cent in the model 5 to 83 per cent in model 6 . This result shows that an increase in FDI of one per cent will increase the $i p$ by around 0.0489 per cent. After putting FDI in the model, the 
coefficient of $\dot{k}$ becomes positive and significant, although $\dot{y}$ remains and emp has the same correct sign, it is a little bit smaller.

In the labour productivity growth model, it is important to consider that output may have endogenous problems [10]. According to this study, output might be affected by the world economy and the level of competition among producers [24]. Therefore, this study uses a dummy variable to capture the effect of the world economic down turn [4] which began in the year 2000. After testing for endogenous problems, the Hausman test does not reject the null hypothesis that variables are exogenous . The result is that a null hypothesis has not been rejected, which is consistent with the study of Quandt and Rosen [16] who mentioned that the exogenous ${ }^{3}$ variable can produce results that are just as good as those generated by the more theoretical assumption of endogeneity.

\section{Conclusion}

Since the early 1990s, Thailand has consistently reduced tariffs and non-tariff barriers and lifted restrictions on FDI. A temporary setback occurred during the Asian crisis in 1997/98, but it was corrected afterwards. Statistics in general show that (1) the labour productivity of the manufacturing sector has been increasing over time, (2) there are widespread mismatches among the share of manufacturing growth and the share of manufacturing employment, indicating a possible expansion of skilled employment.

Trade liberalisation in Thailand raised two wider questions regarding the labour market one with regard to the link with labour productivity and the other the link with skilled workers. Regarding the first question, the results tend to show that there is some indication of a link between trade liberalisation and labour productivity growth. With respect to the second question, a positive correlation has been recorded in (1) trade liberalisation and skilled employment (Table 1), and (2) skilled employment and labour productivity growth. The growth in skilled employment is a contributor to labour productivity growth (Table 2)in the Thai manufacturing sector while the overall growth in manufacturing employment has a negative effect on labour productivity. This type of evidence matches with conventional explanations for the beneficial allocation of trade liberalisation and demanding skills training for potential future industrial growth. However, the models linking trade liberalisation, skilled employment, and labour productivity growth at a micro level would give more concrete results.

\footnotetext{
${ }^{3}$ Ho: Variables are exogenous. The test of endogeneity shows that (i) Durbin (score) Chi2 (1) $=0.141861(\mathrm{p}=0.7064)$ and (ii) Wu-Hausman F $(1,45)=0.125521(\mathrm{p}=0.7248)$ and the null hypothesis is not rejected.
} 


\section{Appendix}

Table 3 Appendix 1: Manufacturing Average Tariff Rate from 1991 to 2007

\begin{tabular}{|c|c|c|c|c|c|c|}
\hline Industrial & 1991 & 1994 & 1997 & 2000 & 2003 & 2007 \\
\hline 15 Food and beverage & 43.33 & 42.5 & 41.6 & 39.7 & 32.78 & 31.15 \\
\hline 16 Tobacco products & NA & 60 & 51.4 & 60 & 60 & 60 \\
\hline 17 Textiles & 60 & 53.33 & 30.1 & 20.2 & 24.35 & 20.32 \\
\hline 18 Wearing apparel & 75 & 65 & 41.3 & 46.9 & 36.79 & 27.4 \\
\hline 19 Dressing of leather & 100 & 70 & 28 & 19.4 & 21.1 & 18.33 \\
\hline 20 Wood and products of wood and cork & 15 & 40 & 17.9 & 16.1 & 15.2 & 9.3 \\
\hline 21 Paper and paper products & 10 & 10 & 18.4 & 15.2 & 12.66 & 5.06 \\
\hline 22 Publishing, printing and reproduction of recorded media & NA & 17.5 & 20 & 17.1 & 15.02 & 3.66 \\
\hline 23 Coke refined petroleum products and nuclear fuel & 30 & 27.5 & NA & 5.7 & 3.44 & 5.13 \\
\hline 24 Chemicals and chemical products & 30 & 57.5 & 15.9 & 10.1 & 6.49 & 4.15 \\
\hline 25 Rubber and plastics products & 30 & 55 & 33.7 & 25.3 & 23.53 & 8.6 \\
\hline 26 Other non-metallic mineral products & 20 & 20 & 24.4 & 17.2 & 14.75 & 9.98 \\
\hline 27 Basic metals & 30 & 18 & 10.8 & 9 & 9.66 & 2.68 \\
\hline 28 Fabricated metal products, except machinery and equipment & 30 & 32.5 & 22.9 & 18.7 & NA & 11.74 \\
\hline 29 Machinery and equipment n.e.c. & 41.67 & 47.33 & 10 & 8.5 & NA & 5.13 \\
\hline 30 Office, accounting and computing machinery & 30 & 30 & NA & NA & 7.72 & 2.15 \\
\hline 31 Electrical machinery and apparatus n.e.c & 40 & 40 & 16.5 & 13 & NA & 6.59 \\
\hline 32 Radio, television and communication equipment and apparatus & 45 & 45 & NA & NA & NA & 6.68 \\
\hline 33 Medical, precision and optical instruments, watches and clocks & 40 & 35 & NA & NA & NA & 4.65 \\
\hline 34 Motor vehicles, trailers and semi-trailers & 21.67 & 31.67 & NA & NA & 43.44 & 30.24 \\
\hline 35 Other transport equipment & 32.5 & 32.5 & 26.3 & 25.6 & 16.45 & 13.25 \\
\hline 36 Furniture & 70 & 60 & 40 & 20 & NA & 15.17 \\
\hline 37 Recycling & NA & NA & NA & NA & NA & NA \\
\hline
\end{tabular}

Source: World Integrated Trade Solution [25]

Table 4 Appendix 2: Correlation Matrix of Explanatory Variables

\begin{tabular}{|c|c|c|c|c|c|c|c|c|}
\hline Variables & $\dot{k}$ & $\dot{y}$ & tariff & skill & eimp & i_im & & $x F L$ \\
\hline$\dot{k}$ & 1 & & & & & & & \\
\hline$\dot{\boldsymbol{y}}$ & -0.1149 & 1 & & & & & & \\
\hline tariff & -0.3179 & 0.174 & 1 & & & & & \\
\hline skill & -0.0219 & 0.1367 & -0.0123 & 1 & & & & \\
\hline exip & 0.0186 & 0.2205 & 0.1167 & -0.1605 & 1 & & & \\
\hline i_im & 0.2467 & -0.1544 & -0.2681 & 0.0091 & 0.0903 & 1 & & \\
\hline$x$ & 0.0477 & 0.0517 & -0.2266 & 0.0857 & 0.1565 & 0.6542 & & 1 \\
\hline$F D I$ & -0.2433 & 0.6415 & -0.1037 & 0.1394 & 0.0311 & 0.0421 & 0.2173 & \\
\hline
\end{tabular}

Source: Calculated by the author 


\section{References}

1. Bank of Thailand (2011)Macro Economic Indicators. Bank of Thailand, Bangkok.

2. Beaudry P, Collard F (2002) Why Has the Employment-Productivity Tradeoff among Industrialized Countries Been So Strong?. NBER Working Paper,Massachusetts NBER, pp. 1-43.

3. Blanchard OJ, Diamond P (1992)The Flow Approach to Labor Markets. The American Economic Review, 82(2):345-359

4. Crotty J. (2000) Structural Contradictions of the Global Neoliberal Regime', Economics Department, University of Massachusetts, Massachusetts.

5. Davis DR, Harrigan J (2011)Good Jobs, Bad Jobs, and Trade Liberalization. Journal of International Economics, (84):26-36

6. Gujarati DN (2003), Basic Economietrics, McGraw-Hill Companies, New York.

7. Hine RC, Wright PW (1998)Trade with Low Wage Economies, Employment and Productivity in Uk Manufacturing. The Economic Journal, 108(450):1500-1510

8. Ing LY (2009) Lower Tariff, Rising Skill Premium in Developing Countries: Is It a Coincidence?. The World Economiy: 1115-1133.

9. Jonsson G, Subramanian A (2001)Dynamic Gains from Trade:Evidence from South Africa. International Monetary Fund, 48(1): 197-244

10. Leon-Ledesma MA (2000)Economic Growth and Verdoorn's Law in the Spanish Regions, 1962-91. International Review of Applied Economics,40(1):55-69

11. Levinsohn J (1999)Employment Responses to International Liberalization in Chile. Journal of International Economics, 47:321-344

12. Manprasert S (2012) Overview of the Thai Economy, accessed July 2012, http://pioneer.netserv.chula.ac.th/ msompraw/Overview.pdf

13. Melitz MJ (2003) The Impact of Trade on Intra-Industry Reallocations and Aggregate Industry Productivity. Econometrica,71(6): 1695-1725

14. National Social and Economic Development Board (2009), National Social and Economic Development Plans, accessed 1 Feb. 2010, http://www.nesdb.go.th/Default.aspx?tabid=62

15. Phan P (2004)Trade Liberalization and Manufacturing Performance in Thailand 1990-2000. School of Economics, The University of Wollongong, Wolllongong.

16. Quandt RE, Rosen HS (1989) Endogeneous Output in an Aggregate Model of the Labour Market. National Bureau of Economic Research,(74):394-400

17. Ramstetter ED (2004) Labor Productivity, Wages, Nationality, and Foreign Ownership Shares in Thai Manufacturing, 1996-2000. Journal of Asian Economics,14:861-884

18. Ramstetter ED, Sjoholm F (2006), Multinational Corpoerations in Indonesia and Thailand, Palgrave Macmillan, New York.

19. Sjholm F (1997) Exports, Imports and Productivity: Results from Indonesian Establishment Data. Working Paper No. 33 August 1997, Stockholm School of Economics, Stockholm, 1-33

20. Statistical Office (2007) Industrial Survey', National Statistical Office. National Statistical Office, Bangkok.

21. Verhoogen E (2008) Trade, Quality Upgrading, and Wage Inequality in the Mexican Manufacturing Sector. The Quarterly Journal of Economics, 123(2):489-530.

22. Wachtel HM (1984) Labor and the Economy, Academic Press, Inc. , Florica.

23. Weiss J (1992) Export Response to Trade Reform: Recent Mexican Experience. Development Policy Review, 10(1):43-60.

24. Wilkinson B, Gamble J, Humphrey J, Morris J, Anthony D (2001)The New International Division of Labour in Asian Electronics: Work Organization and Hu. Journal of Management Studies,38(5):675-695

25. World Bank (2011) World Integrated Trade Solution, accessed September 6, http://wits.worldbank.org/wits/index.html 